\title{
The Effects of Polluted River Water to the Riverside Groundwater, Case in Niger River in Koulikoro
}

\author{
Drissa Traore $^{1} \&$ Qian Hui ${ }^{1,2}$ \\ ${ }^{1}$ Chang An University, Xi'an, China \\ ${ }^{2}$ Department Environmental Sciences and Engineering, Chang An University, Xi'an, China \\ Correspondence: Drissa Traore, Chang An University, Xi’an, China. E-mail: ibabosst@gmail.com
}

\author{
Received: September 19, 2014 Accepted: October 11, 2014 Online Published: November 5, 2014 \\ doi:10.5539/enrr.v4n4p238 \\ URL: http://dx.doi.org/10.5539/enrr.v4n4p238
}

\begin{abstract}
Ground water demand is increasing in many African nations due to a number of factors. The growth of population, climate change, increase pollution of rivers, and insufficient number of purifying stations and waste water treatment (or almost nonexistent) have pushed to the water authorities for exploitation of underground water. These underground /groundwater have a relationship with surface water. Then what can be the effects of polluted River to its riverside groundwater? To explore the answer of this question and for the prevention sustainable and a better integrated management of water resources, we will do in-depth study on "the relationship between river water and riverside ground".

In Koulikoro region the results of this research show that Surface waters have poor bacteriological quality, the amount of total coliforms is very high, and accordingly Niger River's waters are not allowed for consumption without treatment. However the river water can be safely used for laundry, bath, sports and recreation. Generally the Groundwater quality is good despite increased salinity has been observed sporadically. We found also that for the entire region of Koulikoro the average infiltration rate is less than $19.8 \%$ of the gross rainfall.
\end{abstract}

Keywords: river water, groundwater, aquifer, infiltration, Mali, Koulikoro, Niger River

\section{Introduction}

\subsection{The Problem Statement}

Water is a precious natural resource in the world and without it life cannot exist. According to the latest assessment report of new age international publishers, there is about $97.2 \%$ to global water resources in the world is salt mainly in oceans and $2.8 \%$ is only available as fresh water. Out of this $2.8 \%$ of fresh water, about $2.2 \%$ is available as surface water (glaciers, icecaps, lakes, and an others forms) and $0.6 \%$ is groundwater. Groundwater is a huge resource but limited.

Groundwater demand in many African nations is greatly increasing due to a number of factors: the growth of population, climate change, increased pollution of rivers, and insufficient number of purifying station and wastewater treatment. Inadequate sanitation has led waterborne diarrheal and other enteric illnesses to become the leading cause of death on the continent, accounting for over $40 \%$ of all child deaths in the Sub-Saharan region (McMurray, 2007). Groundwater is also one of our most important sources of water for irrigation.

\subsection{Exploration of Importance Problem}

At one time, groundwater purity and availability were taken for granted, and it was a hidden resource; but over the past few years, it is undeniably true that polluted water is becoming the biggest threat to human live. For better management of fresh water resources, it is necessary for water scientists to understanding the effects of polluted river water to the riverside groundwater. This will raise the question of understanding the interaction between river water (surface water) and groundwater. In other words, understanding what can be the consequences of polluted River to riverside groundwater. However, it's very difficult to observe and measure the interaction. Thus we have to understand three phenomena to know: Infiltration, percolation and interflow.

Infiltration is movement of water into and through soil. The percolation is described as being the properties related to the connectivity of large numbers of objects which individually have some spatial extent, and for which their spatial relationships are relevant and statistically prescribed. The three basic assortments that percolation theory 
came are: bond, site, and continuum. In hydrology, interflow is the lateral movement of water in the unsaturated zone that returns to the surface or enters a stream prior to becoming groundwater.

\subsection{Objectives}

The major scope of this research will cover to the following.

- To characterize the aquifer system in Koulikoro region.

- To investigate and advice to riparian populations on groundwater related issues. And also regarding potential water problems.

- To create an analytical studies of aquifers in order to lay the foundations of sustainable and rational management of water resources in Koulikoro region of Mali.

\subsection{Description of the Study Area}

The region of Koulikoro is bordered by the Islamic Republic of Mauritania to the north, the region of Kayes to the west, by Guinea and to the region of Sikasso to the south, and by the region of Segou to the east. With an area of 90,210 km2, or 7.2\% of the Mali's territory, Koulikoro Region is divided into seven (7) largest cities "cercles" (Table 1). The region is situated entirely within the tropical zone. In the region, there are four types of climates: the north Guinean climate, the south Sudanese climate, the North Sudanese climate and the South Sahelian climate, with alternating during the year a rainy season (May to October) and a dry season (November to April).The average annual rainfall is between 700 to $1200 \mathrm{~mm}$ in a normal year. The average temperatures are between 26 and $33^{\circ} \mathrm{C}$.

Koulikoro has a large river system which includes the Niger River with a long of $250 \mathrm{~km}$; The Baoule, the Bagoe, the Baninfing, Sankarani and Bani with 120, 90, 70, 40 and $20 \mathrm{~km}$ long respectively. The Niger, Baoule and Sankarani are permanent streams. The 2012/2013 hydrological year has been marked by the maximum flow of about 199 occurred on 21st May 2013 and the minimum flow of 149 which occurred on 29th May 2013 with a year mean volume of 179. The total flow volume at Koulikoro, from 1st June 2012 to 30th April 2013 was about 35.68 $\mathrm{Km}^{3}$ (http://nigerhycos.abn.ne January 13, 2014 07:05PM ). The region also has ponds and lakes. Koulikoro water resources come mainly from the rains that are only meteoric waters which the region enjoys.

Table 1. Areas and populations

\begin{tabular}{lllllllll}
\hline Cercles & Koulikoro & Banamba & Dioïla & Kangaba & Kati & Kolokani & Nara & Total \\
\hline Area $\left(\mathrm{Km}^{2}\right)$ & 7260 & 7500 & 12000 & 5150 & 16300 & 12000 & 30000 & 90210 \\
Population & 178650 & 165468 & 387565 & 88931 & 598038 & 215221 & 184128 & 1828001 \\
\hline
\end{tabular}

According to PIRT (Projet Inventaire des Ressources Terrestres) the different types of soils in Koulikoro are characterized in their majority by their poverty, their acidity and their structural instability. Table 2 below gives the soils and their characteristics.

Koulikoro is a major trade and industrial town on the Niger River and provides opportunities for navigation.

Table 2. Soils and their characteristics

\begin{tabular}{lllll}
\hline $\begin{array}{l}\text { Soils } \\
\text { characteristics }\end{array}$ & Lateritic and alluvial & $\begin{array}{l}\text { Sandy lateritic and } \\
\text { clayey }\end{array}$ & $\begin{array}{l}\text { ferralitic and } \\
\text { ferruginous }\end{array}$ & very sandy \\
\hline Location & $\begin{array}{l}\text { Kangaba, Kati, Kourouba, } \\
\text { Baguinéba, Néguela, } \\
\text { Sanankoraba, Siby, Kati }\end{array}$ & $\begin{array}{l}\text { Koulikoro, Banamba, } \\
\text { Toukoroba, kolokani }\end{array}$ & Dioïla & $\begin{array}{l}\text { Nara, Banamba } \\
\text { (Sébété, Boron) }\end{array}$ \\
\hline $\begin{array}{l}\text { Pluviometer } \\
(\mathrm{mm})\end{array}$ & 1200 to 900 & 950 to 750 & 1000 to 950 & Around 450 \\
\hline
\end{tabular}

\section{Method}

\subsection{Description}

To achieve our goals, we have developed a survey based on the documentation and on the collection of data. Some of our data were obtained from the Sigma 2 database. The Sigma 2 (Geographic Information System of Mali) 
database is an archive compiled by the Malian government containing information for over 20,000 wells drilled throughout the country since the 1970s, including their completion details, yield estimates, and water chemistry. We performed the analysis and synthesis of data by comparing the quality of groundwater with that of the world health organization and similarly for River water. In this context of our research, some groundwater data were taken from Bamako. To estimate the water quantity infiltrates, we have determined the average infiltration rate for the entire region of Koulikoro by using empirical equations established by the authors of the Hydrogeological Synthesis of Mali.

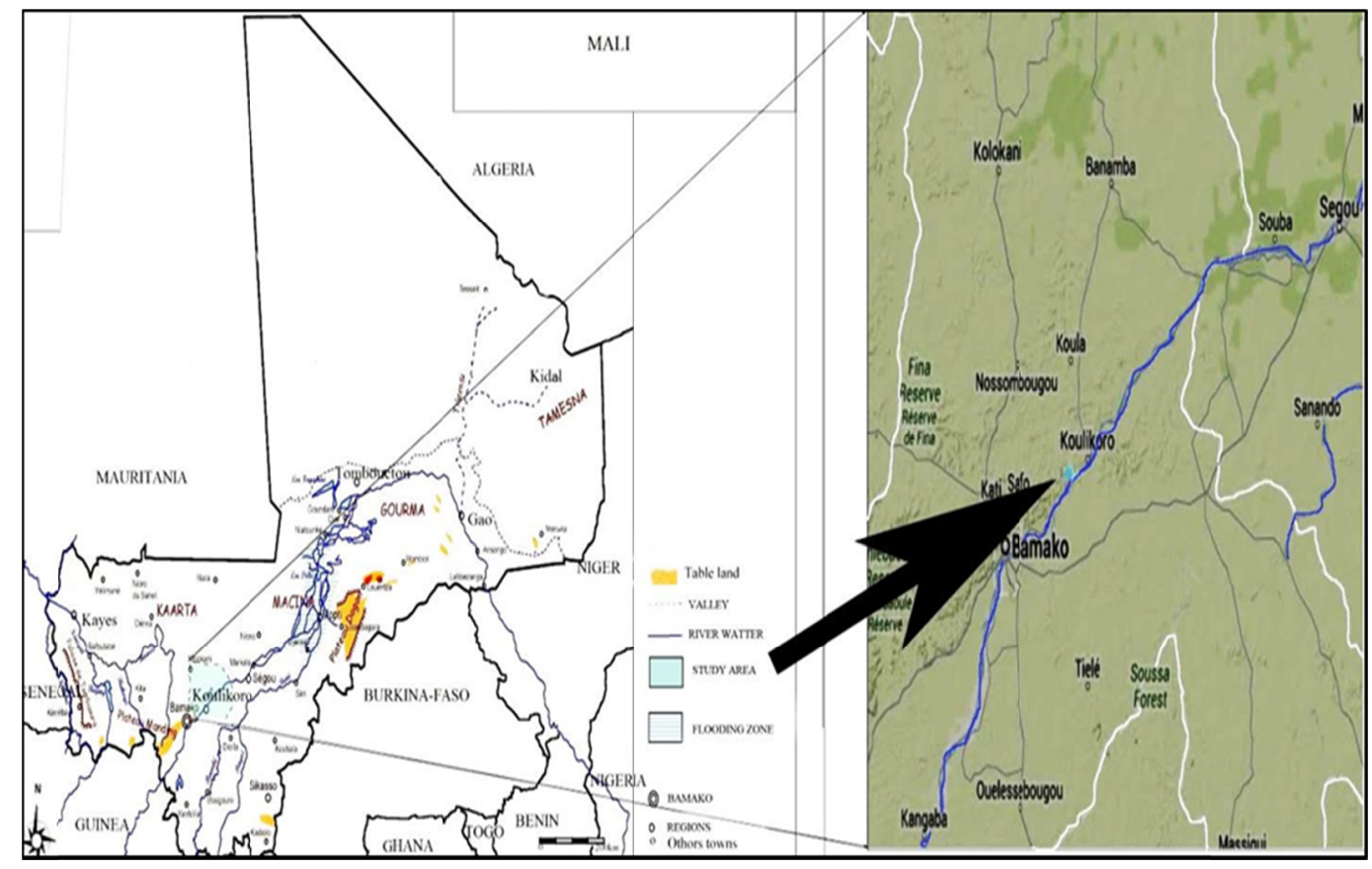

Figure 1. Study area

\subsection{Data Base}

\subsubsection{Pollutions Sources}

The pure water is clear colourless, no discernible taste or smell. A good knowledge of the physicochemical and bacteriological characteristics of the water can help us to determine the degree of pollution, in order to prevent contamination and public health. The water pollution is an alteration which makes water unsafe and disrupts the aquatic ecosystem. It can affect river water and groundwater. In the midst of research, we found that the worst environmental pollutants are: industrial pollution, agriculture pollution, outdoor garbage, interior living garbage and accidental pollution.

The River Niger is the fourth longest river in Africa (4 $200 \mathrm{~km}$ ).It takes its source in the Fouta Djalon mountains of Guinea and flows northeast through the Mali. The Niger River plays an important role in the life of vast population: its floodplains are used for cultivation cotton, rice and contributed to production of energy (Electricity power).Its important fish resources are benefited for the populations. We consider the Niger as a vital artery. Despite the function performed by the Niger River, it is more and more exposed to pollution.

Human and animal organic waste (domestic wastewater, dyeing, water from craft activities, and water from slaughterhouses) Figures 2 and 3.Industrial waste waters and effluents very often uncontrolled. Organic and chemical fertilizers and pesticides from agricultural areas. Pesticides include two class chemicals: insecticides and herbicides. There are also risks of an exceptional pollution: like the massive oil spill following incidents handling storage tanks or as a result of accident vehicles of transportation fuel.

\subsubsection{River Water Quality Data}

In the context of establishing a system of hydro-ecological monitoring of the Niger River, some measurements and samplings were carried out from 1995 to 1999. To these measurements are added to those made by the IRD (Institute of Research for the Development). These data allowed us to obtain the following Table 4. 
Table 3. surface water quality (source UN-WATER/WWAP/2006/10/ Mali)

\begin{tabular}{ccccccccccc}
\hline & \multicolumn{8}{c}{ Average value/WHO average value (mg/l) } \\
\cline { 2 - 9 } years & $\begin{array}{c}\text { Dissolved } \\
\text { Oxygen }\end{array}$ & \multicolumn{2}{c}{$\mathrm{NO}_{3}^{-}$} & \multicolumn{2}{c}{$\mathrm{NH}_{4}^{+}$} & $\mathrm{PO}_{4}^{3-}$ & \multicolumn{2}{c}{$\begin{array}{c}\text { Total coliforms (without adding system) } \\
\text { colonies/100 }\end{array}$} \\
\hline 1980 & 12 & - & 0.01 & 3 & 0.0 & 0.5 & 0.00 & - & 0 \\
1996 & 8 & - & 0.05 & 3 & 0.1 & 0.5 & - & - & $>100$ & 0 \\
1999 & 6.7 & - & 1.2 & 3 & 0.11 & 0.5 & 0.11 & - & - & 0 \\
\hline
\end{tabular}

(-) No value Significant; WHO: World Health Organization.

\subsubsection{Rainwater Quality Data}

Hydrological year in Niger basin is always starting from June till May. The quality of rainwater reflects that of air. It can evolve significantly in space and time. The air pollution is caused by transportation, solid waste combustion, combustion in households (wood), and, soap factories (see Figure 4 below).

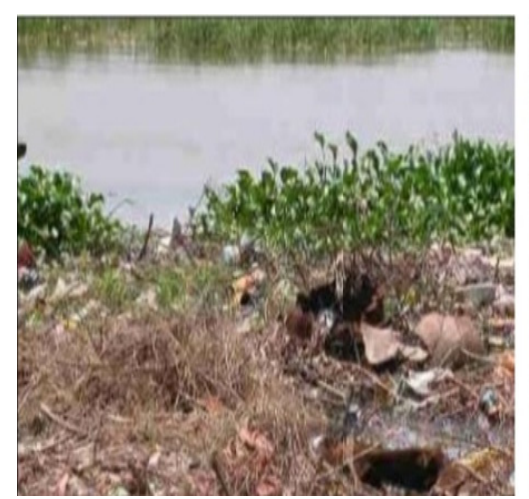

Figure 2. Pollution by garbages and plants

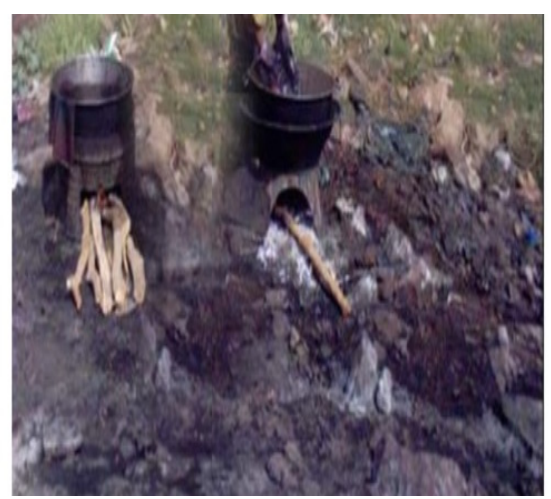

Figure 3. Environment pollution by dyeing

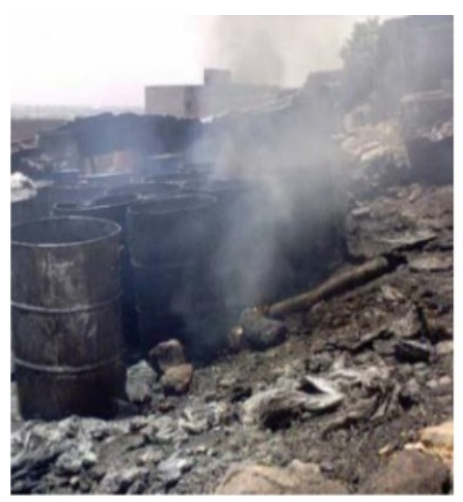

Figure 4. Local soap factory

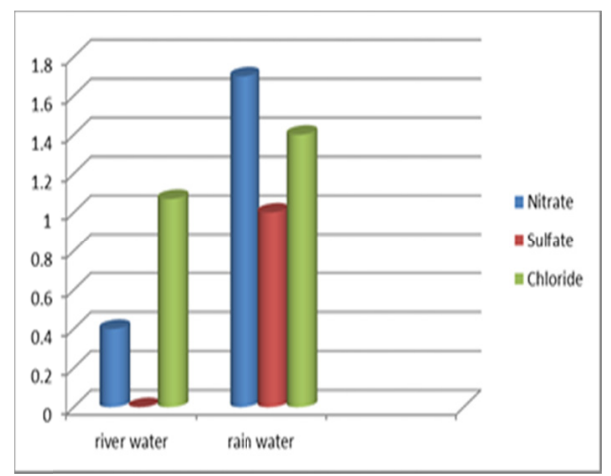

Figure 5. Average concentrations of Nitrate, Sulphate (sulfate) and Chloride of rainwater and of Niger River to Banankoro

Existing data on the quality of rainwater show that annual average mineralization of the waters of River Niger is superior to that of rain water. In contrast the average concentrations of chloride $\left(\mathrm{Cl}^{-}\right)$, nitrate $\left(\mathrm{NO}_{3}^{-}\right)$and sulphate $\left(\mathrm{SO}_{4}^{-2}\right)$ in rainwater, are superior to those of river waters (Figure 5).

\subsubsection{Groundwater Quality Data}

An aquifer is a geologic formation with sufficient interconnected porosity and permeability to store and transmit significant quantities of water under natural hydraulic gradients[a]. The aquifers found in the Niger River Basin can generally be classified into fractured aquifers and inter-granular aquifers. In the fractured aquifers, the groundwater does not move through pores inside the rock body but through fractures and fissures. This is generally 
due to the absence of passable pores. In contrast to the fractured aquifers in the inter-granular aquifers, the groundwater flows mainly through passable pores.

Koulikoro region is characterized by the aquifer fractured semi-continuous type at the centre and south; the aquifer fractured discontinuous type at the northwest; and the aquifer continuous- generalize at the northeast. The quality of groundwater is related to lithology. In the region groundwater are few mineralized with dry residues less than $0.4 \mathrm{mg} / \mathrm{l}$ and with conductivity less than $500 \mu \mathrm{S} / \mathrm{cm}$. The necessary information on groundwater is given in Table 4 .

Table 4. Groundwater quality

\begin{tabular}{lllllll}
\hline Element/substance & Nitrate $\left(\mathrm{NO}_{3}^{-}\right)$ & Fluoride(F) & Iron(Fe) & Uranium(U) & Iodine(I) & Manganese(Mn) \\
\hline Groundwater & $<0.1-7.3$ & $<0.2-1.7$ & $0.01-1.7$ & $0.05-106$ & $1-440$ & $0.002-3.8$ \\
WHO's guideline & 50 total nitrogen & 1.5 & - & $1.410^{3}$ & - & 0.5 \\
\hline
\end{tabular}

All units in $\mathrm{mg} / \mathrm{l}$ except for (U) and (I) in $\mu \mathrm{g} / \mathrm{l}$.

\subsubsection{Groundwater Chemistry}

Surface water and groundwater systems interact then groundwater chemistry and surface-water chemistry can not be dealt with separately.They interact throughout all landscapes from the mountains to the oceans. Water chemistry provides undoubtedly a lot of information in the knowledge of groundwater. Generally, the nature of groundwater depends on land which cross them. Its chemical composition is the result of the physical action of several agents.

\subsubsection{The Water Supply}

According to the Statistical Yearbook 2003, in Koulikoro region there are two types of aquifers: the alluvial aquifers (5 to 15 meters approximately in depth) and ground fracturing aquifers (20 to 40 meters in depth approximately).Aquifers are being exploited and generally of good quality. In Koulikoro region, only the cities of Koulikoro and Kati are supplied with water by the Energy Company of Mali (EDM: Energie Du Mali), and others towns and villages are supplied by boreholes and wells. It has 4,843 modern water points. The water needs of the population in the region of Koulikoro by city (2005-2008) are given by the Figure 6.The conquest of the solution to the problems of water has led in 2009 to the separation of both water and electricity, putting an end to the monopoly of the company energy of Mali (EDM - SA), which until now had in charge of the two sectors. It is as a result of this separation that the Government, by order $N^{o} 10-039 / \mathrm{P}-\mathrm{RM}$ and 10-040/P-RM of August 5, 2010, decided the creation of Malian society of heritage of drinking water (Somapep: Société Malienne de Patrimoine de l'Eau Potable) and the Malian society's management of drinking water (Somagep: Société malienne pour la gestion de l'eau potable).

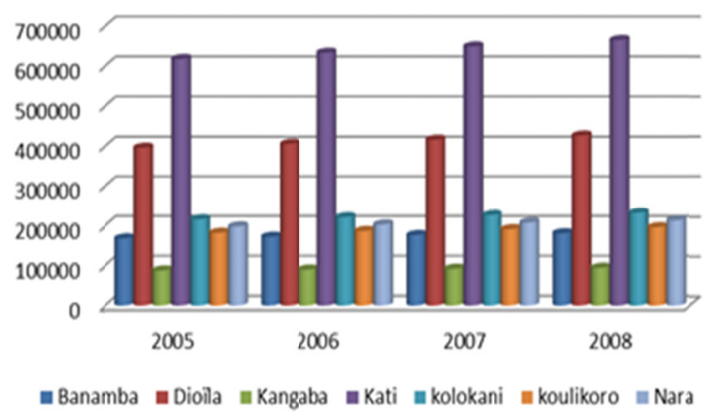

Figure 6. Water needs

\subsubsection{Piezometer}

Piezometric network is and will remain essential for establishing the water balance and determination of aquifer reserves. Piezometer is used for measuring the soil water pressure at the depth at which the slits lie. If water has a pressure greater than atmospheric pressure it will enter the piezometer. The piezometer is influenced by the rainfall, the runoff (surface water), the topography and the geology. 
Koulikoro region has a total of 84 piezometers in boreholes. Only 17 piezometers are equipped and others are subject to manual measurements. The temporal evolution of the piezometric shows a general decline in levels, and some piezometers immediately respond to rainfall variations.

\subsubsection{Aquifer Natural Recharge}

Aquifer recharge is depending on many factors: climate, land use, vegetal covers ...etc. Precipitation and river water percolate downward. In our study area, both (rainwater and river water) are essentially way to feed groundwater.

According to the authors of the Hydrogeological Synthesis of Mali (Robert, 1997), the relationship between infiltration (I) and average annual rainfall (P) is given by one of the following equations:

(a) rainfall regions between $300 \mathrm{~mm}$ and $700 \mathrm{~mm}, \mathbf{I}=\mathbf{0 . 3 0} \mathbf{-} \mathbf{7 0}$

(b) areas with greater than $700 \mathrm{~mm}$ annual rainfall, $\mathbf{I}=\mathbf{0 . 1 1 P}+\mathbf{6 3}$

$\mathrm{I}$ and $\mathrm{P}$ are measured in millimetres $(\mathrm{mm})$. Note that these equations were obtained after adjustment approach (approximation).

Thus, knowing the average annual rainfall, the infiltration rate of the study area is given by the Figure 7 .

For estimating groundwater recharge by river, we used the Zero flux plane method. According to Amitha Kommadathit relies on the location of a plane of zero hydraulic gradients in the soil profile. Recharge over a time interval is obtained by summation of the changes in water contents below the plant. The position of the zero flux planeis usually determined by tensiometers.

The flow of water through the pores within a soil volume is generally considered as laminar, thus the velocity is proportional to the hydraulic gradient. This is Darcy law given by the following formula: $q=V A=k i A=k \frac{\Delta h}{L} A$.

Where V: velocity of flow; K: coefficient of permeability of aquifer soil; A: cross-sectional area of the aquifer, and $i$ hydraulic gradient.

\section{Results and Discussion}

We found that for the entire region of Koulikoro the average infiltration rate is less than $19.8 \%$ of the gross rainfall (Figure 7). This is approximately the same result like as the authors of the Hydrogeological Synthesis for all Mali (Average infiltration rate less than 20\%). So this research allowed us to do some verification. On the other hand, it is well known groundwater and Rivers water feed each other. Interactions between groundwater and surface water basically proceed in two ways: groundwater flows through the stream bed into the stream (gaining stream), and stream water infiltrates through the sediments into the groundwater (losing stream). We got the goal which is to show the consequences of polluted Rivers on riverside groundwater. Indeed, it is very clear the polluted Rivers can easy reach its shallow groundwater.

Tableau 3 shows total coliforms $>100$ colonies per $100 \mathrm{ml}$. The coliform is very high. So River water is not allowed for consumption without treatment. The quality of surface water is deteriorating from year to year. Nitrogen in the form of nitrate $\left(\mathrm{NO}_{3}^{-}\right)$indicates contamination with sewage. Excessive phosphorous concentrations in drinking water can cause health s' problems, while essential for growth.

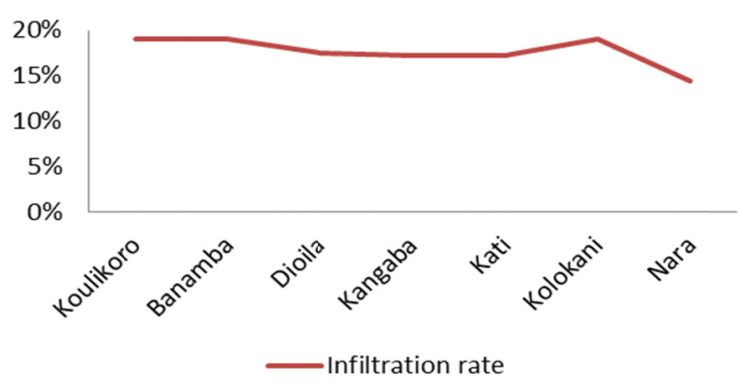

Figure 7. average infiltration rate

In most cases, we can say groundwater is cleaner than surface water. For Koulikoro aquifer, Information available suggests that groundwater is of good quality. However, increased salinity has been observed sporadically. Groundwater is heavily used for public supply. Around $55 \%$ of the population of the capital city of Bamako uses 
water from aquifer resources and more than $60 \%$ in Koulikoro region. We realized that: the information on the residence time of water in groundwater aquifer is necessary in the field of drinking water supply especially for risk analysis in cases of pollution and for the analysis of ecosystems. It is a commonplace that ecosystems depend on groundwater, vice versa. We know that the isotopic parameters of a stream vary very little. We have also rendered account that the knowledge of water balance is very important, which can be determined and managed by meteorological, hydraulic and hydrological studies. Those will take into account all the elements of the balance (rainfall, Evapotranspiration, runoff, infiltration, recharge and discharge).

In the closest flooding area to the River, the aquifer Continental terminal/Quaternary recharges by River would have estimated of order of 100,000 $\mathrm{m}^{3}$ year ${ }^{-1} \mathrm{~km}^{-2}$ (Anonym, 1990). An area of $510^{-3} \mathrm{~km}^{2}$ located a few $\mathrm{km}$ from koulikoroba (specified surface by the arrow Figure 1) the aquifer recharges by River would have estimated of order of $500 \mathrm{~m}^{3} \mathrm{~km}^{-2}$.

\section{Acknowledgments}

The paper is supported by Chinese scholarship council and Malian government. The authors would like to thank very much anyone who made their contribution for realization of this paper in particularly Dr Li Peiyue and Mr. Qiao Liang.

\section{References}

Andersen, I., \& Golitzen, K. G. (Eds.). (2005). The Niger river basin: A vision for sustainable management. World Bank Publications.

Cleary, R. W. (2003). The groundwater pollution and hydrology course.

Conway, D., Persechino, A., Ardoin-Bardin, S., Hamandawana, H., Dieulin, C., \& Mahé, G. (2009). Rainfall and water resources variability in sub-Saharan Africa during the twentieth century. Journal of Hydrometeorology, 10(1), 41-59.

Diagnostic regional de Koulikoro situation de référence sur base d'analyse documentaire.

Gourcy L. (1994). Fonctionnement Hydro Chimique De La Cuvette Du Fleuve Niger (Mali).

International Water Management Institute. (2012). Groundwater availability and use in subsaharan Africa a review of 15 countries. Sri Lanka.

IWACO, Delft hydraulics. (1996). le Niger supérieur.

Kalbus, E., Reinstorf, F., \& Schirmer, M. (2006). Measuring methods for groundwater-surface water interactions: a review. Hydrology and Earth System Sciences, 10(6), 873-887.

Karamouz, M., Szidarovszky, F., \& Zahraie, B. (2003). Water resources systems analysis. Boca Raton, FL: Lewis Publishers.

Martin Jager and Sven Menge. (2012). The Niger River Basin, An Assessment of Groundwater Need.

Matthew, M. (2012). Hydrogeology lecture notes (2.3 ed).

Ministre De La Sante. (2010). Analyse de la situation et estimation des besoins (ASEB) en Sante et Environnent au Mali dans le cadre de la mise en ouvre de la déclaration de Libreville.

Programme des Nations Unies pour le Développement. (1990). Synthèse hydrogéologique du mali, Direction de l'Hydraulique et de l'Energie. Bamako, Mali.

Raghunath. H. M. (2006). Hydrology (revised 2nd ed.). Hydrology new age international publishers.

UN-WATER/WWAP. (2006). Mali: La mise en valeur des ressources en eau.

Valenza, A., Grillot, J. C., \& Dazy, J. (2000). Influence of groundwater on the degradation of irrigated soils in a semi-arid region, the inner delta of the Niger River, Mali. Hydrogeology Journal, 8(4), 417-429.

Viessman Warren, Jr. L. L. G. ( 1997). Introduction of hydrology (4th ed.).

Zhao Y, Wang W, Bruen M, Zhao X. (2013). International symposium on water resources and pollution control in arid/semi-arid regions. 21-23 June 2013.

\section{Copyrights}

Copyright for this article is retained by the author(s), with first publication rights granted to the journal.

This is an open-access article distributed under the terms and conditions of the Creative Commons Attribution license (http://creativecommons.org/licenses/by/3.0/). 